\title{
Differential Response to Water Deficit in Chili Pepper (Capsicum annuum L.) Growing in Two Types of Soil Under Different Irrigation Regimes
}

\author{
Israel Macias-Bobadilla ${ }^{1}$, Marcela Vargas-Hernandez ${ }^{2}$, Ramon G. Guevara-Gonzalez ${ }^{1}$, \\ Enrique Rico-Garcia ${ }^{1}$, Rosalia V. Ocampo-Velazquez ${ }^{1}$ and Irineo Torres-Pacheco ${ }^{1 \text {,* }}$ \\ 1 Faculty of Engineering, Autonomous University of Queretaro, Biosystems Engineering Group, \\ Campus Amazcala, Highway Chichimequillas, km 1 S/N, El Marques C.P., Queretaro 76265, Mexico; \\ ie.ti.israel@gmail.com (I.M.-B.); ramon.guevara@uaq.mx (R.G.G.-G.); ricog@uaq.mx (E.R.-G.); \\ rosov05@yahoo.com.mx (R.V.O.-V.) \\ 2 Faculty of Engineering, Autonomous University of Queretaro, Campus Amealco, Highway Amealco \\ Temazcaltzingo, km 1, Amealco de Bonfil C.P., Queretaro 76850, Mexico; marcela.vhz@gmail.com \\ * Correspondence: irineo.torres@uaq.mx; Tel.: +52-44-2192-1200
}

Received: 24 July 2020; Accepted: 27 August 2020; Published: 30 August 2020

\begin{abstract}
Chili pepper (Capsicum spp.) is one of the most economically important horticultural crops in the world; its production for the food and pharmaceutical industries has been increasing worldwide. The economic importance of this crop is due, in part, to the nutraceutical properties derived from its secondary metabolism. Drought is the main environmental factor that affects crop production. Nevertheless, studies involving water deficit have considered short-term responses to sharp water deficit rather than long-term acclimation processes through moderate and gradually increasing water deficits, which omitted the dynamics and profile of the secondary metabolism that are part of the plant's defence system against this stress factor. The present study aimed to identify the different mechanisms that chili pepper plants use to cope with drought stress using a progressive decrease and increase of water availability, conditions that commonly occur for crops in open fields. Four treatments were applied as follows: gradual water deficit (GWD), initial waterlogging with gradual water deficit (IWGD), sudden water deficit with gradual recovery (SWDR), and no deficit of water (NDW). These conditions should represent a more real situation similar to that faced by plants in the agricultural environment. In order to evaluate the response mechanisms associated with these water deficits, changes in phenological variables, proline accumulation, and the gene expression of phenylalanine ammonia-lyase $(P A L)$, chalcone synthase $(C H S)$, peroxidase $(P O D)$, and superoxide dismutase $(S O D)$ were measured in chili pepper plants growing on land under different irrigation regimes in two contrasting soil types in areas where chili pepper plants are cultivated in central Mexico. The variables evaluated showed a differentiated response of the mechanisms in plants growing under different levels of water deficit. Given the differential response observed for the gene expression and morphological and biochemical variables studied in chili pepper plants against different water regimes, in this work, this may have implications for more efficient use of water in crops with high nutraceutical content, in addition to prospects for using products derived from secondary metabolism in the pharmaceutical industry.
\end{abstract}

Keywords: soil; drought stress; defence mechanism

\section{Introduction}

The genus Capsicum spp. (chili pepper) includes 25 to 30 species, of which the following five are cultivated: C. annuum L., C. frutescens L., C. chinense Jaqch, C. baccatum, and C. pubescens. These five 
species have been domesticated and are currently cultivated [1]. Chili pepper (Capsicum spp.) is one of the most economically important horticultural crops worldwide; it is among the 50 main food products according to The Food and Agriculture Organization of the United Nations (FAO). The consumption of chili fruits as a fresh food or seasoning has been increasing worldwide [2]. This increase is also due to it is used as an additive in the food and pharmaceutical industries [3]. The economic importance of this crop is due, in part, to the nutraceutical properties derived from its secondary metabolism. It is an important source of bioactive compounds such as vitamins A, E, and C; phenolic compound; flavonoids; and capsaicinoids [2]. These compounds, all secondary metabolites, are produced in response to different sources of stress [4]. Drought stress occurs when the water available in the soil decreases, and environmental conditions contribute to its loss in the soil [5]. During a period of drought, plants face conditions of inadequate water to boost their physiological activity, which causes senescence and stunted growth [6]. Drought stress is a multidimensional stress that generally leads to changes in the physiological, morphological, ecological, biochemical, and molecular traits of plants [7]. At the physiological level, a metabolite that has been associated recurrently with response to drought stress is proline. Proline is an osmolyte that accumulates in plant cells to maintain the cell turgor pressure [8]. Other mechanisms imply that enzymes, such as phenylalanine ammonia-lyase (PAL, EC 4.3.1.5), chalcone synthase (CHS, EC 2.3.1.74), peroxidase (POD, EC 1.11.1.7), and superoxide dismutase (SOD, EC 1.15.1.1), have essential roles in the response to drought stress by plants. PAL is responsible for the nonoxidative deamination of L-phenylalanine for the formation of trans-cinnamic acid in plants [9]. Under conditions of drought stress, PAL activity increases [10,11]. It is the first step in the metabolism of phenylpropanoids, that is, the activation of PAL triggers the production of phenolic compounds, such as flavonoids, anthocyanins, and tannins, among others $[5,12]$. CHS is an enzyme related to secondary metabolism; this enzyme catalyzes the first step in the biosynthetic pathway of flavonoids [10]. In tobacco (Nicotiana tabacum), the overexpression of CHS generates plants with higher drought tolerance [13]. On the one hand, in chili pepper, there is an association of the gene expression of the CHS enzyme and the production of flavonoids with drought tolerance and UV-B [14]. On the other hand, POD and SOD are part of the antioxidant defence system. SOD is responsible for the dismutation of the superoxide anion to $\mathrm{O}_{2}$ and $\mathrm{H}_{2} \mathrm{O}_{2}$ [15]. In chickpea, drought stress induces an increase in the activity of the peroxidase and superoxide dismutase enzymes, in addition to the proline content [16]. Currently, the efficient use of water in crops is of great importance. The study of different irrigation regimes will give a better understanding regarding crop water use in crop production. Most previous studies involving water deficit have considered short-term responses to sharp water deficit rather than long-term acclimation processes through moderate and gradually increasing water deficits. Therefore, future studies should not only consider periods of exposure to water deficit but also a decrease or progressive increase in water availability to the plant which better represents a real situation that plants face in open fields. This study aimed to identify the different mechanisms that chili pepper plants use to cope with drought stress by providing a progressive decrease and increase of water availability. The different irrigation regimes applied were a gradual water deficit (GWD), initial waterlogging with gradual water deficit (IWGD), sudden water deficit with gradual recovery (SWDR), and no deficit of water (NDW). These were applied on two contrasting soil types (clay and sandy) where chili pepper plants are cultivated in central Mexico. We studied the impacts of these conditions on morphological variables, proline accumulation, and the expression of phenylalanine ammonia-lyase $(P A L)$, chalcone synthase $(C H S)$, peroxidase $(P O D)$, and superoxide dismutase $(S O D)$ genes. These factors were used as indicators of the possible mechanisms used by chili pepper plants grow on land under different irrigation regimes. 


\section{Materials and Methods}

\subsection{Samples Collection}

Clay soil samples were taken at the coordinates $20^{\circ} 35^{\prime} 44^{\prime \prime} \mathrm{N}, 100^{\circ} 49^{\prime} 37^{\prime \prime} \mathrm{W}$. Twenty representative samples were collected using the standardized methods for the collection of soil samples. Sandy soil was collected from the coordinates $18^{\circ} 19^{\prime} 47,622^{\prime \prime} \mathrm{N}, 97^{\circ} 10^{\prime} 23,498^{\prime} \mathrm{W}$. Twenty representative samples were collected. The characteristics of the soil are shown below in Table 1.

Table 1. Physical characteristics of soils used in the study.

\begin{tabular}{ccc}
\hline Characteristic & Sandy & Clay \\
\hline Clay & 21 & 55 \\
Sandy & 59 & 25 \\
Silt & 20 & 20 \\
Organic matter & 8.71 & 1.81 \\
DAP $\left(\mathrm{g} / \mathrm{cm}^{3}\right)$ & 1.55 & 1.4 \\
\hline
\end{tabular}

\subsection{Establishment of the Experiment}

The plant material used for the present study was Capsicum annuum L. cv. ROMEL F-1 from the CALORO ${ }^{\circledR}$ seed house, lot JR01107, and purity 99\%. It was treated with Thiram and had uniform relative maturity. In the greenhouse, the chili pepper plants were handled in culture bags. The experimental design used was split plots as follows: A whole plot with two levels of soil type, sandy soil and clay soil, and a strip plot with four water stress regimes, i.e., gradual water deficit (GWD) (Figure 1A), initial waterlogging with gradual water deficit (IWGD) (Figure 1B), sudden water deficit with gradual recovery (SWDR) (Figure 1C), and no deficit of water (NDW) (Figure 1D). The experimental unit consisted of three plants and six repetitions. A randomized block design was utilized.
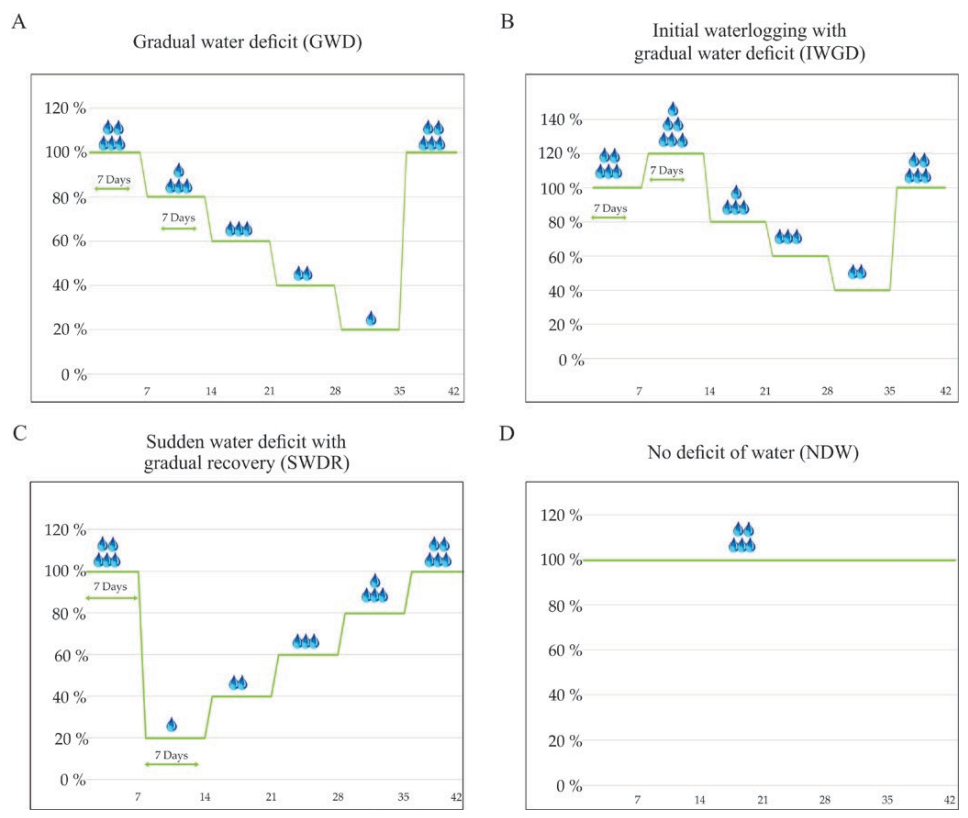

Figure 1. The different water stress treatments evaluated in the study. The figure shows the treatments at different types of water stress. (A) gradual water deficit (GWD); (B) Initial waterlogging with gradual water deficit (IWGD); (C) Sudden water deficit with gradual recovery (SWDR); (D) No deficit of water (NDW). The Y-axis represents the percentage of the volume of water that corresponds to the field capacity and the $\mathrm{X}$-axis represents the days during which the irrigation volume was applied. 


\subsection{Calculation of Stress Type}

To calculate the water available (AD) to the irrigation sheet, the field capacity (CC) formula for irrigation was used based on the texture (sandy (AR), clay (AC)) and the organic matter (MO) content according to Silva et al. (1) [17]. For calculation of the permanent wilting point (PMP), the formula described by Silva et al. (2) [17] was used. The available water was calculated with the following Formula (3) for every ten centimeters of soil, and the apparent density (DAP) was estimated in $\mathrm{g} / \mathrm{cm}^{3}$ using the soil texture class table from the Soil Survey Staff USDA. The soil was considered to be a single horizon; the irrigation sheet was calculated for $30 \mathrm{~cm}$ with a volume of soil for the culture bags of $0.00340 \mathrm{~m}^{3}$. The characteristics of the soil from which the amount of water used to irrigate the plants was calculated are shown in Table 1, and the chemical characteristics are shown in Table 2.

$$
\begin{gathered}
\mathrm{CC}=21.977-0.186(\mathrm{AR})+2.601(\mathrm{MO})+0.127(\mathrm{AC}) \\
\mathrm{PMP}=-5+0.74 \mathrm{CC} \\
\mathrm{AD}=(\mathrm{CC}-\mathrm{PMP}) * \mathrm{DAP}
\end{gathered}
$$

Table 2. Chemical characteristics of soils used in the study.

\begin{tabular}{ccc}
\hline Characteristic & Sandy & Clay \\
\hline Nitrogen & $248 \mathrm{KN} / \mathrm{Ha}$ & $39 \mathrm{KN} / \mathrm{Ha}$ \\
Phosphorus & $17.6 \mathrm{mg} / \mathrm{kg}$ & $1.66 \mathrm{mg} / \mathrm{kg}$ \\
Calcium & $6387.02 \mathrm{mg} / \mathrm{kg}$ & $5091.11 \mathrm{mg} / \mathrm{kg}$ \\
Magnesium & $1317.04 \mathrm{mg} / \mathrm{kg}$ & $1301.47 \mathrm{mg} / \mathrm{kg}$ \\
Potassium & $328.81 \mathrm{mg} / \mathrm{kg}$ & $990.19 \mathrm{mg} / \mathrm{kg}$ \\
Sodium & $9.97 \mathrm{mg} / \mathrm{kg}$ & $263.78 \mathrm{mg} / \mathrm{kg}$ \\
\hline
\end{tabular}

\subsection{Irrigation System}

The stress conditions were induced by 4 1/h drippers Rainbirt ${ }^{\circledR}$ (Rainbird CP075, Asuza, CA, USA), and the precision irrigation control system was managed by a SmartReley Schneider ${ }^{\circledR}$ model zelio ${ }^{\circledR}$ (Schneider Electric Automation GmbH, Lahr, Germany) and an independent solenoid valve system for each stress level and soil type, as shown in Figure 2.

\section{IRRIGATION SYSTEM SCHEME}

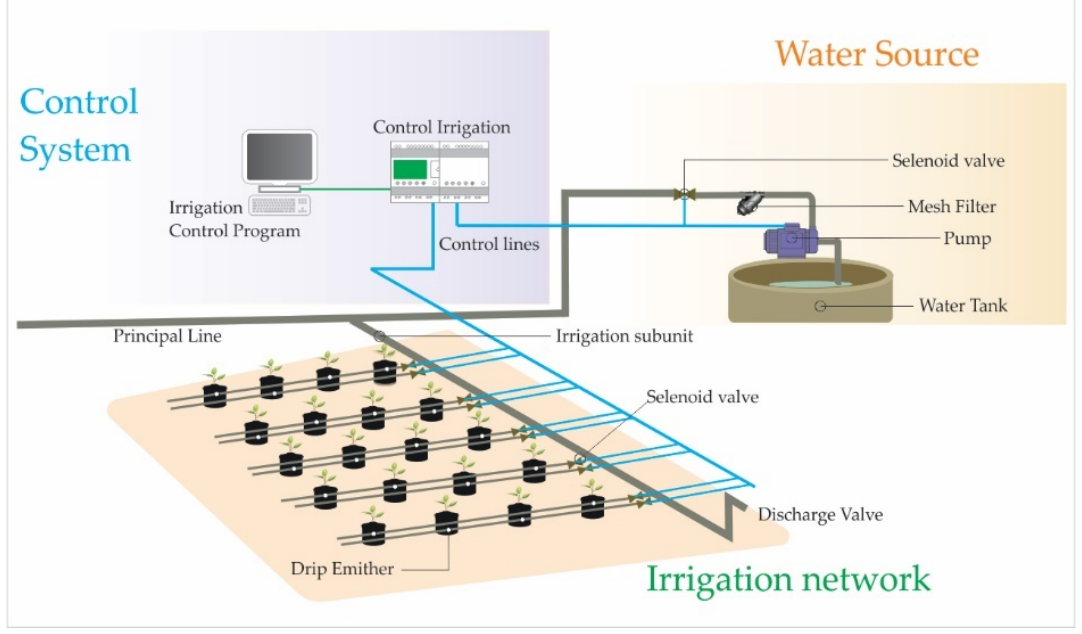

Figure 2. Irrigation control system used for each drought-stress condition evaluated. The scheme represents one of the experimental plots. 


\subsection{Measurement of the Morphological Variables}

The plant height was measured at the beginning of the application of the water stress treatments, and then again at the end of each stress treatment. For the determination of this characteristic, a measuring tape was used. The tape was placed at the base of the main stem at the height of the root ball and was extended to the apex of growth. The stem diameter was measured at the base of the stem; the readings were measured at the beginning of the application of treatments, and then again at the end of each stress treatment using a digital Vernier caliper with a resolution of $0.01 \mathrm{~mm}$. The numbers of fruits and leaves were quantified at the end of the application of the treatments.

\subsection{Determination of Proline Concentration in Capsicum annuum L. Leaves}

Proline determination was performed according to the method proposed by Bates et al. [18] with some modifications. First, the leaf samples were ground with liquid nitrogen. A quantity of $0.05 \mathrm{~g}$ of plant material was homogenized in $1 \mathrm{~mL}$ of $3 \%$ aqueous sulfosalicylic acid, and this was centrifuged at $12,000 \mathrm{rpm}$ for $10 \mathrm{~min}$. The aqueous phase was reacted with ninhydrin acid and glacial acetic acid in a 1:1:1 ratio. The reaction was incubated at $100{ }^{\circ} \mathrm{C}$ for $1 \mathrm{~h}$, and then the reaction was stopped in an ice bath. The reaction mixture was extracted with toluene by vigorously mixing for 15 to $20 \mathrm{~s}$. Finally, samples were read at an absorbance of $520 \mathrm{~nm}$. The standard curve was developed at concentrations of $50,40,30,20,10,5$, and $0 \mathrm{~g} / \mathrm{mL}$ of L-proline. The results are reported as $\mu$ moles proline/g of fresh weight material.

\subsection{RNA Extraction and cDNA Synthesis}

The samples were ground with liquid nitrogen. Total RNA was extracted from pepper leaves using Trizol reagent, according to the manufacturer's instructions. Subsequently, the ZYMO RESEARCH DIRECT ZOL RNA MINIPREP (Zymo Research, Irvine, CA, USA) kit was purified with RNA according to the manufacturer's specifications. Concentration, purity, and quality were determined using an RNA (concentration, quality, and purity) Thermo Scientific ${ }^{\mathrm{TM}}$ AquaMate 8000 UV-Vis Spectrophotometer (Thermo Fisher Scientific, Waltham, MA, U.S.). cDNA synthesis was performed with the Thermo Scientific $^{\text {TM }}$ First Strand cDNA Synthesis Kit MAXIMA FIRST STRAND (Thermo Fisher Scientific, Waltham, MA, USA) for RT-qPCR according to the manufacturer's instructions.

\subsection{RT-qPCR Conditions and Analysis}

The qRT-PCR analysis was carried out on 96-well plates with the CFX96 Touch Deep Well ${ }^{\mathrm{TM}}$ Real-Time PCR Detection System (Bio-Rad). The primers used in this study were those previously reported and used in a study in Chile by Rodríguez-Calzada et al. [14] and included the following: phenylalanine ammonia-lyase (PAL; AF081215) forward $5^{\prime}$-att cgc gct gca act aag at $-3^{\prime}$ and reverse $5^{\prime}$-cac cgt gta agg cct tgt tt-3'; chalcone synthase (CHS; FJ705842.1) forward $5^{\prime}$-tcg acc ctc agt caa acg ac- $3^{\prime}$ and reverse $5^{\prime}$ - tgg gcc acg gaa agt aac tg- $3^{\prime}$; superoxide dismutase (MnSOD; AF036936.2) forward $5^{\prime}$-ctc tgc cat aga cac caa ctt- $3^{\prime}$ and reverse $5^{\prime}$-cca agt tcg gtc ctt taa taa- $3^{\prime}$; peroxidase (POD; FJ596178.1) forward $5^{\prime}$-gca gca ttc ctc ctc cta ct- $3^{\prime}$ and reverse $5^{\prime}$-att tct ttg cct tgt tgt tg- $3^{\prime}$; and beta-tubulin ( $\beta$-TUB; EF495259.1) forward $5^{\prime}$-gag ggt gag tga gca gtt c- $3^{\prime}$ and reverse $5^{\prime}$-ctt cat cgt cat ctg ctg tc- $3^{\prime}$. These were all provided by Eurofins, Germany. To the reaction mixture, $5 \mu \mathrm{L}$ of the iQ SYBR Green Supermix (Bio-Rad), $2 \mu \mathrm{L}$ of cDNA, and the reverse primers (tubulin $0.15 \mu \mathrm{L}$, POD $0.15 \mu \mathrm{L}$, PAL $0.15 \mu \mathrm{L}, \mathrm{CHS}$ $0.9 \mu \mathrm{L}$, and MnSOD $0.15 \mu \mathrm{L}$ ) and forward primers (tubulin $0.3 \mu \mathrm{L}$, POD 0.15 $\mu \mathrm{L}$, PAL 0.3 $\mu \mathrm{L}, \mathrm{CHS} 0.9 \mu \mathrm{L}$, and MnSOD $0.15 \mu \mathrm{L}$ ) were added to reach a final concentration of $10 \mu \mathrm{L}$. The cycling conditions for the amplification of tubulin, PAL, and POD were $5 \mathrm{~min}$ at $94{ }^{\circ} \mathrm{C}$ for 40 cycles $\left(1 \mathrm{~min}\right.$ at $94{ }^{\circ} \mathrm{C}$ followed by $1 \mathrm{~min}$ at $55^{\circ} \mathrm{C}$ ). Finally, melting curve heating of the amplicon was performed through a step of $31 \mathrm{~s}$ at $65^{\circ} \mathrm{C}$ and an increase of $0.5^{\circ} \mathrm{C}$ to $95^{\circ} \mathrm{C}$. In the case of CHS and MnSOD, the alignment temperature changed with a temperature of $58^{\circ} \mathrm{C}$. Samples of each treatment were analyzed in triplicate using 
SyberGreen mix as the fluorophore to quantify by RT-qPCR (BIO-RAD $\left.{ }^{\circledR} \mathrm{C} 1000\right)$, and the results were evaluated using the $2^{-\Delta \Delta} \mathrm{CT}$ method [19].

\subsection{Statistical Analysis}

For all experiments, one-way ANOVA was performed, and for multiple mean comparisons, Tukey's Test with $p=0.05$ was applied. Statistical analysis and graphics were performed using JMP ${ }^{\circledR}$ 13.2.1 software (SAS Institute Inc.).

\section{Results}

\subsection{Effect of Soils on Morphological and Biochemical Variables of Capsicum annuum L.}

The results of this section correspond to the analysis of variance of the experimental design of divided plots. Because an interaction effect was detected between the type of soil and the treatments of irrigation regimes, the results are presented independently because they also show significant effects. In order to evaluate the impacts that sandy and clay soils have on the performance of $C$. annuum, some morphological variables of chili plants grown in these soils were measured. Plant height, stem diameter, leaf number, and the number of fruit values were measured as indicators of plant performance. ANOVA analysis and a comparison of means by using Tukey's test for the morphological variables of chili grown in the two types of soil are shown in Figure 3. There were highly significant differences in the statistical average estimator for height $(20.607 \mathrm{~cm})$, stem diameter $(5.908 \mathrm{~mm})$, number of leaves (39.859), and number of fruit (1.625) of plants grown in the sandy soil as compared with clay soil (18.624 cm, $5.279 \mathrm{~mm}, 25.0$ leaves, and number of fruit, respectively). The values of the comparison of means showed that the estimators of the plants grown in the sandy soil were statistically higher than those of the clay soil.

A

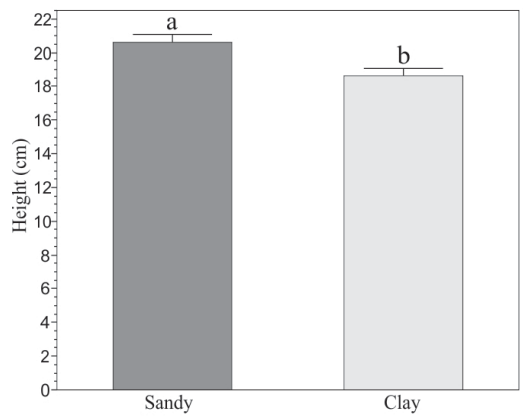

C

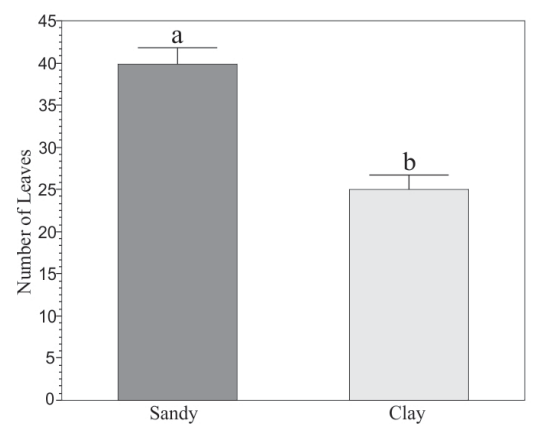

B

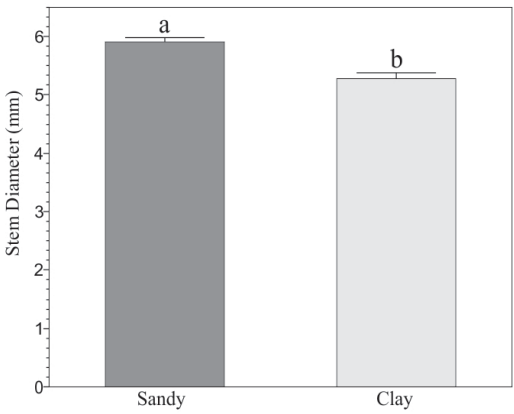

D

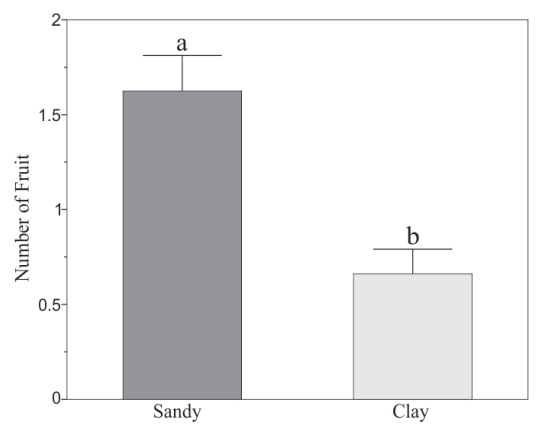

Figure 3. Results of morphological variables of chili pepper plants grown in sandy and clay soils. Comparison of means \pm S.E. by using Tukey's test for the morphological variables that were assessed in sandy and clay soils. (A) Height; (B) Stem diameter; (C) Number of leaves; (D) Number of fruit. In all cases, $p=0.05$. 
In order to determine whether proline is involved in any mechanisms of plant defence in the two types of soil, its concentration in the leaves was measured. The statistical average estimator of proline accumulation in the leaves of the plants grown in clay soil was $1.082 \mu \mathrm{mol} / \mathrm{g}$ of fresh matter as compared with $0.573 \mu \mathrm{mol} / \mathrm{g}$ of fresh matter in sandy soil, showing a significant difference (Figure 4). The results suggest that plants grown in the clay soil turn on osmoregulation as a defence mechanism.

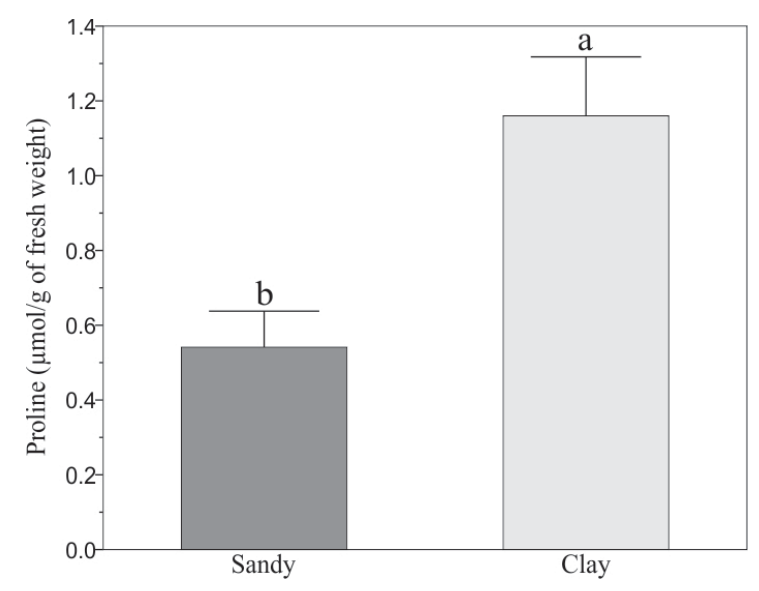

Figure 4. Proline accumulation in chili pepper leaves grown in sandy and clay soils. Comparison of means and S.E. by using Tukey's test. In all cases, $p=0.05$.

In the case of gene expression analysis, there was a non-significant difference.

\subsection{Effects of the Type of Drought Treatment on Some Morphological and Biochemical Variables of Capsicum annuum L.}

The effects of different water application regimes (treatments) on plants grown in sandy and clay soils were evaluated (Figure 5). The water stress treatments evaluated can be seen in Figure 1 . Note that the plants exposed to the GWD treatment were more stressed than those exposed to other treatments with an irrigation volume of $20 \%$ of field capacity maintained for seven days at the end of the trial period (Figure 1A). In the case of the IWGD treatment, the stress was started at field capacity followed by seven days at $120 \%$, irrigation at $80 \%$, and finally, a decrease of $20 \%$ every eight days until the treatment was concluded at $40 \%$ (Figure 1B). The SWDR treatment started with seven days with field capacity irrigation and then seven days of irrigation at $20 \%$ of the field capacity. Then, every week, it increased until field capacity was reached (Figure 1C). Regarding treatment NDW, this was considered to be a control because field capacity was maintained throughout the experiment (Figure 1D).

In Figure 5, it can be seen in all cases that the statistical average estimator values for the morphological variables in the NDW treatment, corresponding to field capacity, were as follows: plant height, $21.954 \mathrm{~cm}$ (Figure 4); stem diameter, $6.23 \mathrm{~mm}$ (Figure 5B); number of leaves, 44.064 (Figure 5C); and number of fruit, 2.516 (Figure 5D). These values were significantly higher than those measured in the rest of the treatments. Thus, the influence of hydric stress on plant behavior can be observed in the morphological characteristics. 
A

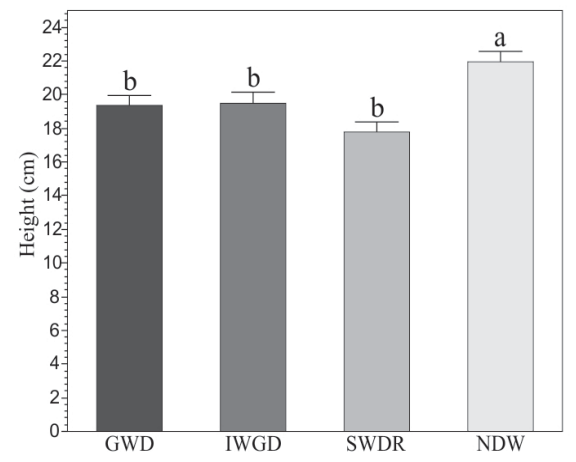

C

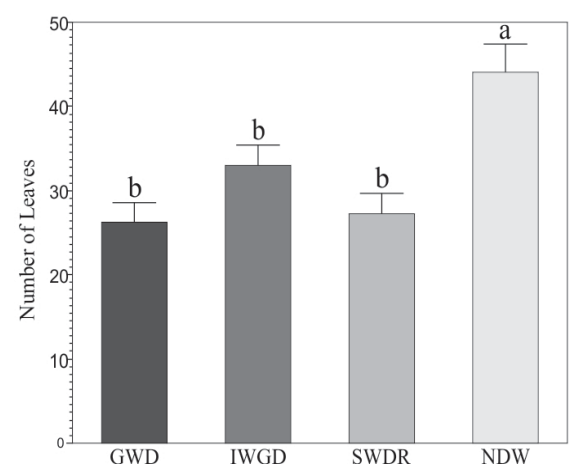

B

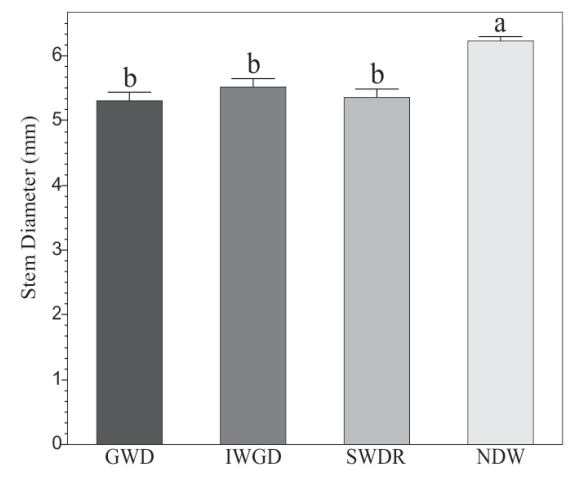

D

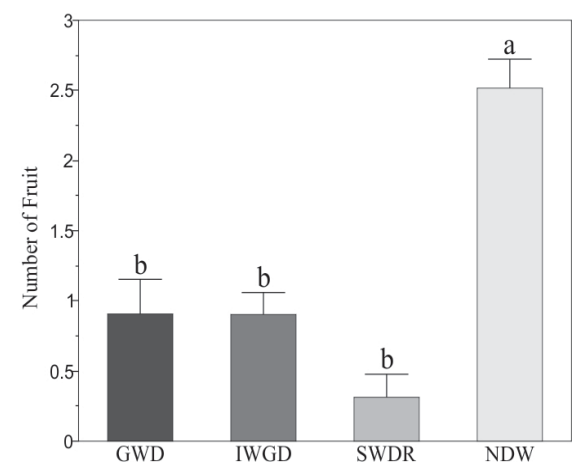

Figure 5. Results of plant performance of chili pepper grown under different water stress regimes. Results of the comparison of means \pm S.E. by Tukey's test of the morphological variables with the response in both types of soil added. (A) Height; (B) Stem diameter; (C) Number of leaves; (D) Number of fruit. In all cases, $p=0.05$. Gradual water deficit (GWD), initial waterlogging with gradual water deficit (IWGD), sudden water deficit with gradual recovery (SWDR), no deficit of water (NDW).

In Figure 6, for the GWD treatment, it can be seen that the relative expression levels of the POD (Figure 6B) and SOD (Figure 6D) genes were significantly higher, 5.529-fold and 2.632-fold, respectively, as compared with the other treatments. On the one hand, in the IWGD treatment, PAL (Figure 6A) expression was significantly higher (21.579-fold) as compared with the rest of the treatments. On the other hand, in SWDR, the proline concentration (Figure 6C) was statistically higher $(1.335 \mu \mathrm{mol} / \mathrm{g})$ than the rest of the other treatments. The NDW treatment did not stand out in terms of any of the mechanisms that can be inferred from proline accumulation and gene expression. 
A

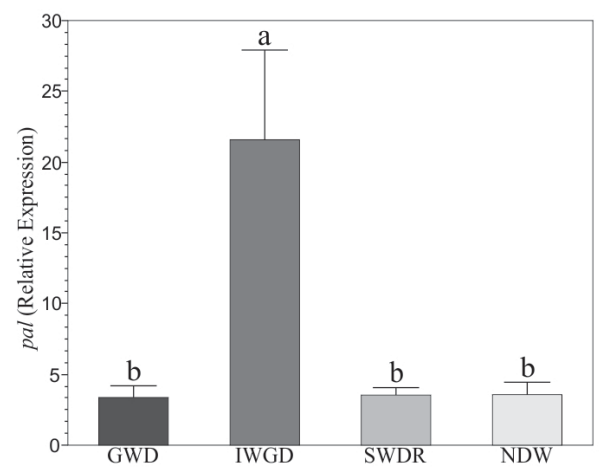

C

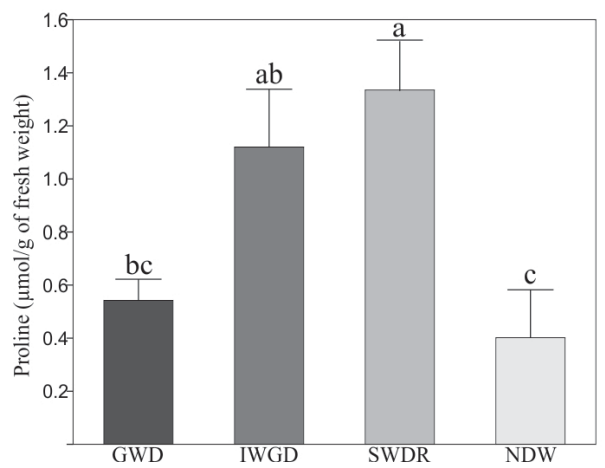

B

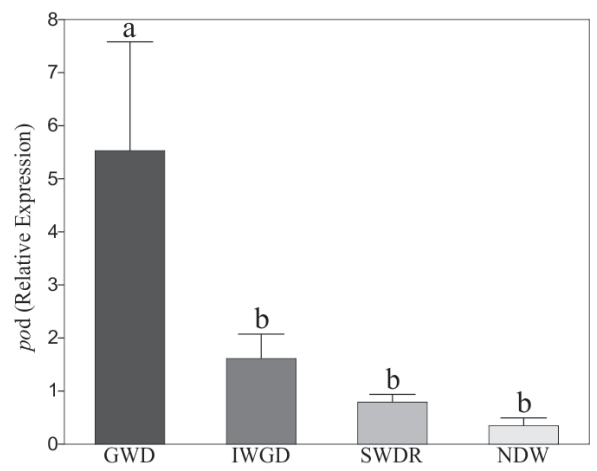

D

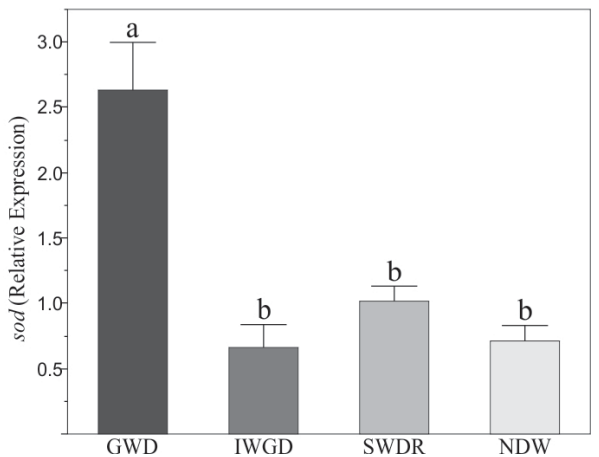

Figure 6. Results of proline accumulation and gene expression associated with the stress response in chili pepper plants grown under different water stress regimes. Results of the comparison of means \pm S.E. by using Tukey's test of the biochemical variables. (A) Phenylalanine ammonia-lyase $(P A L)$; (B) Peroxidase (POD); (C) Proline; (D) Superoxide dismutase (SOD), with the response in both types of soil added. In all cases, $p \leq 0.05$. Gradual water deficit (GWD), initial waterlogging with gradual water deficit (IWGD), sudden water deficit with gradual recovery (SWDR). No deficit of water (NDW).

To determine the effect that the type of soil has on the performance of the plants under different types of water stress (Figure 1), their performance in clay soil was measured (Table 1). The estimators of the mean for the morphological variables for the NDW treatment were significantly higher for height, $21.573 \mathrm{~cm}$ (Figure 7A); stem diameter, $6.212 \mathrm{~mm}$ (Figure 7B); number of leaves, 36.6 (Figure 7C); and number of fruit, 2 (Figure 7D).

In the case of biochemical variables in the IWGD and SWDR treatments, highly significant accumulations of proline (1.55 and $1.65 \mu \mathrm{mol} / \mathrm{g}$, respectively) were observed (Figure $8 \mathrm{~A})$. In terms of gene expression, the GWD treatment showed the highest expression of SOD 3.09-fold (Figure 8B). The stress-response variables showed statistically lower values in the plants treated with the different types of water stress and clay soil; however, only two defence indicators were statistically significant, i.e., proline and SOD gene expression. 
A

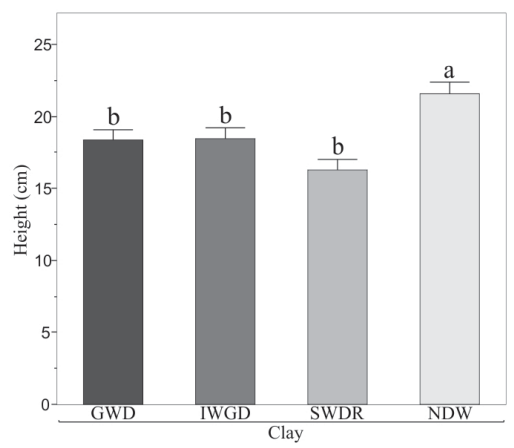

D

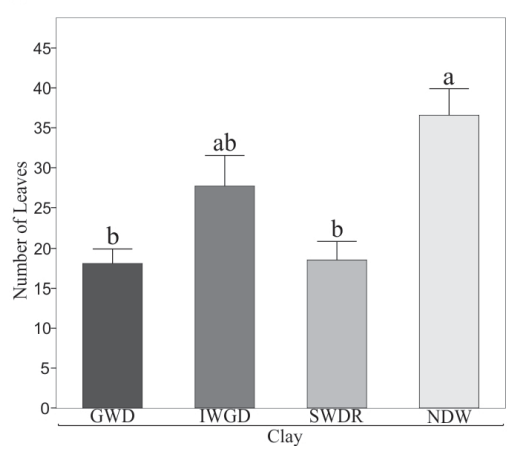

B

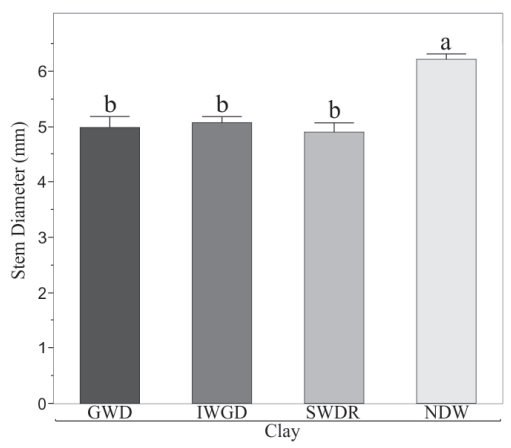

C

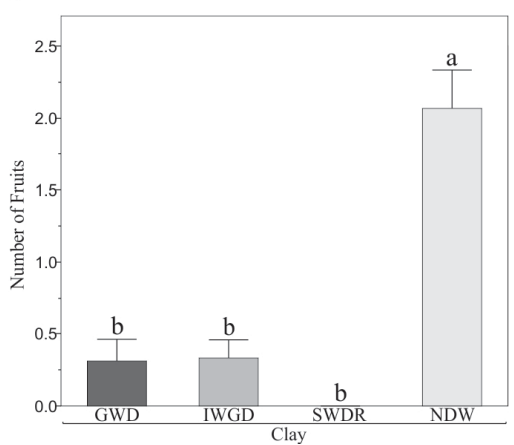

Figure 7. Performance of chili pepper plants grown in clay soil with different irrigation regimes. Results of the comparison of means \pm S.E. by using Tukey's test of the morphological variables. (A) Height; (B) Stem diameter; (C) Number of leaves; (D) Number of fruit. In all cases, $p=0.05$. Gradual water deficit (GWD), initial waterlogging with gradual water deficit (IWGD), sudden water deficit with gradual recovery (SWDR), no deficit of water (NDW).

A

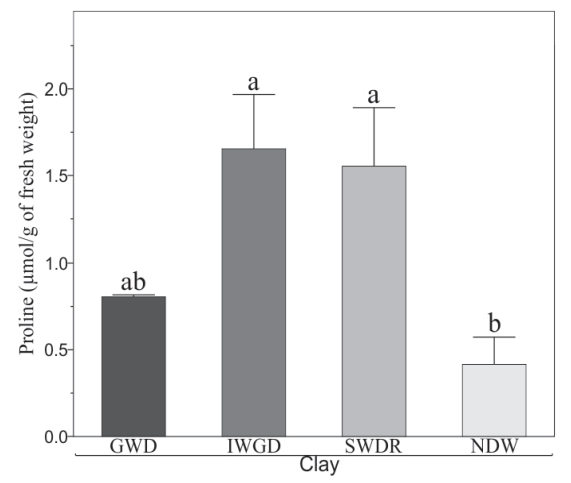

B

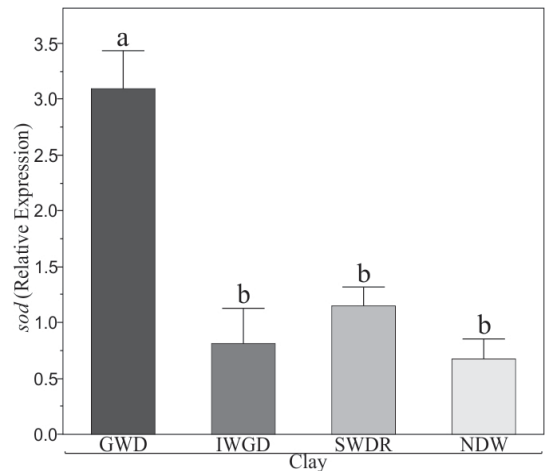

Figure 8. Proline accumulation and $S O D$ gene expression in chili pepper plants grown in clay soil with different irrigation regimes. Results of the comparison of means \pm S.E. by using Tukey's test of the biochemical variables. (A) Proline; (B), Superoxide dismutase (SOD). In all cases, $p=0.05$. Gradual water deficit (GWD), initial waterlogging with gradual water deficit (IWGD), sudden water deficit with gradual recovery (SWDR), no deficit of water (NDW).

The influence of sandy soil (Table 1) on the morphological (Figure 9) and biochemical (Figure 10) variables of chili pepper plants was evaluated. The morphological variables for the NDW treatment were significantly higher for stem diameter, $6.246 \mathrm{~mm}$ (Figure 9A); number of leaves, 51.06 (Figure 9B); and number of fruit, 2.93 (Figure 9C). 
A

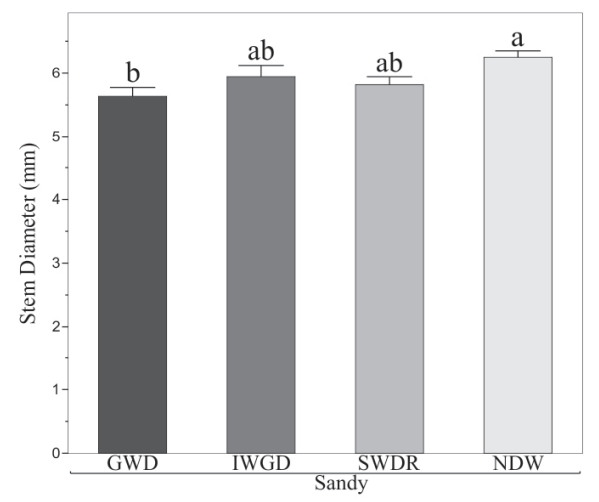

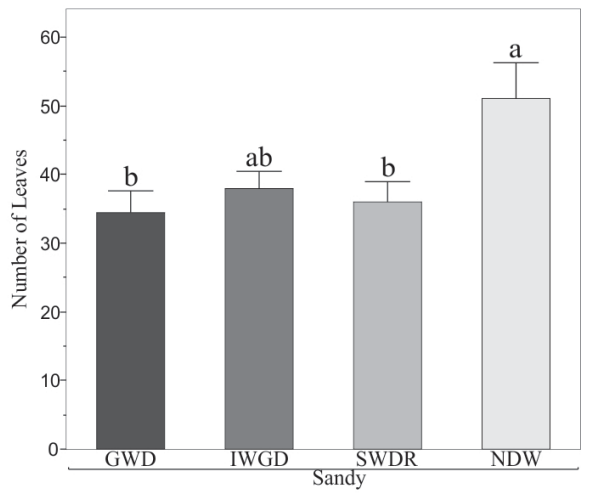

C

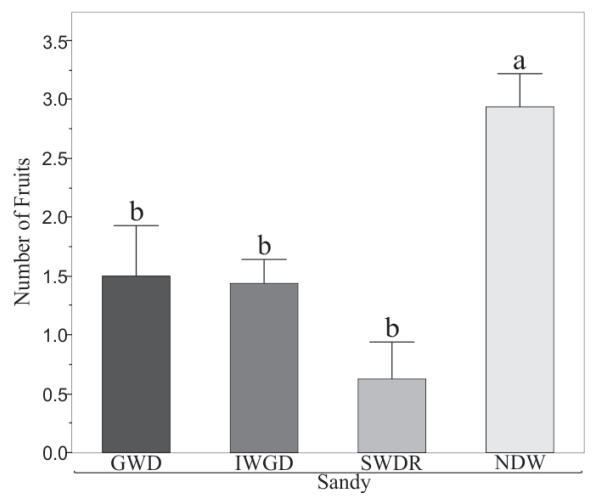

Figure 9. Performance of chili pepper plants grown in sandy soil. Results of the comparison of means \pm S.E. by using Tukey's test of the morphological variables. (A) Stem diameter; (B) Number of leaves; (C) Number of fruit. In all cases, $p=0.05$. Gradual water deficit (GWD), initial waterlogging with gradual water deficit (IWGD), sudden water deficit with gradual recovery (SWDR), no deficit of water (NDW).

In the case of biochemical variables, the IWGD treatment showed highly significant gene expression of PAL, 17.88-fold (Figure 10A) as compared with the other treatments; the GWD treatment showed highly significant gene expression of $P O D, 8.73$-fold (Figure 10B) and SOD, 2.17-fold (Figure 10B). The SWDR treatment displayed highly significant accumulation of proline, $1.11 \mu \mathrm{mol} / \mathrm{g}$ (Figure 10C). The stress-response variables showed statistically significant values in the plants treated with different types of water stress and sandy soil, showing that four stress-response indicators were turned on. 


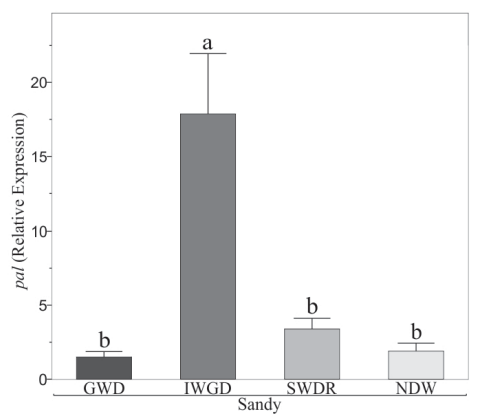

$\mathrm{C}$

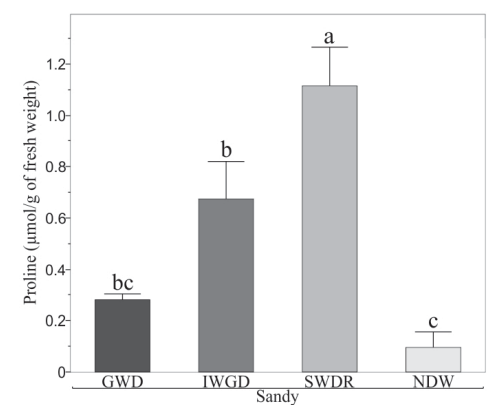

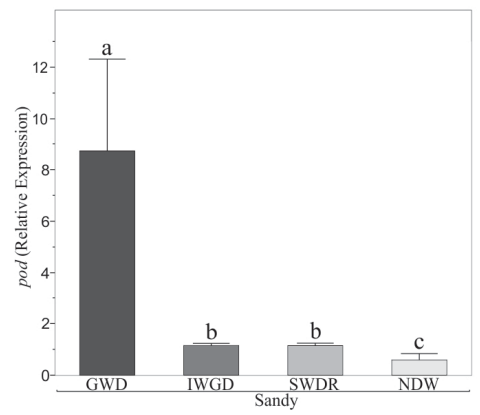

D

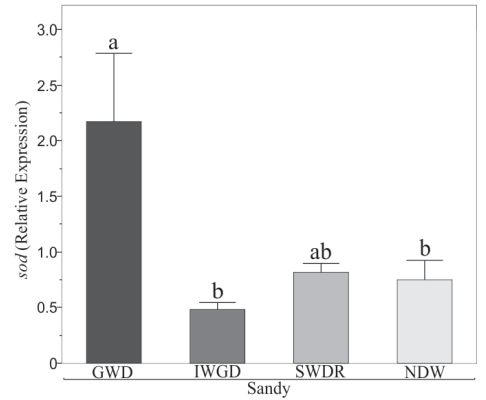

Figure 10. Biochemical variables in chili pepper plants grown in the sandy soil. Results of the comparison of means \pm S.E. by using Tukey of the biochemical variables. (A) Phenylalanine ammonia-lyase $(P A L)$; (B) Peroxidase (POD); (C) Proline; (D) Superoxide dismutase (SOD). In all cases $p=0.05$. Gradual water deficit (GWD), initial waterlogging with gradual water deficit (IWGD), sudden water deficit with gradual recovery (SWDR), no deficit of water (NDW).

\section{Discussion}

The results of the four morphological variables (height, stem diameter, number of leaves, and number of fruit) evaluated as indicators to estimate the stress response in chili pepper plants cultivated under different irrigation regimes representing different drought conditions showed significantly higher values for plants grown in sandy as compared with clay soil. More specifically, our results highlight the importance of the soil type as a component of the environment in agriculture. Concerning the four variables, they influence the survival potential for chili pepper plants exposed to water deficit. The results are consistent with previous reports concerning the role of the soil in phenotypic expression and, in this case, in the plants' response to drought stress [20]. Proline is an osmolyte that plays a role in the osmoregulation mechanism during the response of plants to drought stress, although the precise details of this mechanism are unknown [21]. Proline accumulation has been reported to occur in chili plants exposed to a wide range of environmental stressors, including drought and salinity [22]. In this context, the results observed in Figure 3 suggest that the significantly higher accumulation of proline in plants grown in clay soil was due to the higher sodium content of the soil (Table 2), which led to frequent use of osmoregulation as a mechanism to deal with stress. Thus, a greater effort was required by the plants, giving the plants grown in the sandy soil a disadvantage. According to Kahlaoui et al. [23], this could explain the difference in the observed survival potential. As previously noted, no significant differences were detected regarding the average gene expression of $P A L, P O D, C H S$, and $S O D$ when the data obtained from plants grown in sandy and clay soils were compared. This situation suggests that in both types of soils, the conditions required for growth of the chili plants are available, allowing the genes to be expressed in a similar way.

The results shown in Figures 5 and 6 indicate that, in each treatment, representing different types of drought conditions, the mechanisms used by the plant to cope with stress differed. It should be 
noted that, although the estimators of the means of the morphological variables, i.e., the plant height, stem diameter, the number of leaves, and the number of fruit were statistically equal in the GWD, IWGD, and SWDR treatments (Figure 5), the data suggest that each one uses a different mechanism to cope with drought stress. As shown in Figure 6, in the GWD treatment, there was significantly greater gene expression activity for $P O D$ and $S O D$, which suggests that the plants probably used increased enzyme-type antioxidant activity [24]. To cope with long-term stresses, plants have evolved to counteract the effects of reactive oxygen species (ROS) with antioxidants and antioxidant enzymes that maintain the balance of ROS within the cell [25]. The antioxidant enzymes POD, and SOD play key roles in the detoxification of cellular ROS [26]. Recent evidence indicates that reactive oxygen species (ROS) and reactive nitrogen species (RNS) are among the main intracellular signal transducers that sustain autophagy [27]. Our results reinforce the notion of autophagy as a probable mechanism of the response to drought stress [28,29]. The plants grown under IWGD stress differed from those grown under the other treatments because greater PAL gene expression was induced (Figure 6A). Thus, analogously to reports in tomato, our results suggest that chili pepper plants probably use a mechanism that differentially involves the synthesis of phenols and capsaicinoids [30]. It should be mentioned that in the IWGD treatment, water availability was decreased over time, contrary to in the SWDR treatment, which began with a low amount of water that was subsequently increased. However, plants grown under these two treatments showed greater amounts of proline, which indicates their accumulation on the day of harvest; consequently, the same result was obtained despite the phase of plant recovery or dehydration. Plants that were grown in this drought regime stand out slightly by their accumulation of proline (Figure 6D). Proline is a molecule that has various functions in the plant related to the tolerance of both biotic and abiotic stress. Under drought conditions, proline helps the plant to resist dehydration through its function as an osmolyte [31]. Therefore, our data suggest that plants grown under the conditions of the SWDR treatment had a greater tendency to use osmoregulation to treat this type of stress. The NDW treatment, which was maintained at field capacity (Figure 1D), was always significantly different than the other treatments in terms of the four morphological variables that were evaluated as indicators to estimate the stress response, and among these, the behaviors were statistically the same (Figure 5). However, the results observed in the treatments with different types of drought stress applied showed significant differences in the proline concentration and the gene expression of $P A L, P O D, C H S$, and $S O D$ (Figure 6). This suggests differentiated use of the mechanisms used to cope with drought in the two types of soil. On the one hand, the results of the estimators of the morphological variables in clay (Figure 7) and sandy soil (Figure 9) were similar to those shown in Figure 5. On the other hand, in sandy soil, significant differences in proline accumulation and the gene expression of $P O D, S O D, P A L$, and CHS were observed in each type of water stress (Figure 10). In the case of clay soil, there are two differentiated mechanisms, the GWD treatment showed gene expression of SOD, while IWGD and SWDR accumulated proline for osmoregulation activation (Figure 8).

The results obtained can serve as a basis for the design of irrigation systems aimed at saving water, an increasingly relevant perspective in agriculture. The above would be possible by taking advantage of the knowledge provided in this work regarding the expression of the genes that allow the plant to fight against stress due to lack of water.

In addition, it could be fundamental for designing irrigation strategies that allow an increase in the beneficial bioactive substances for the consumer, either by the increase of the antioxidant capacity related to the activity of the enzymes in the oxidation processes or by means of the synthesis of bioactive like phenols or flavonoids, which are substances that are dedicated to the defence of the plant against stress factors and with potential in the pharmaceutical industry.

\section{Conclusions}

Chili pepper plants reacts differentially to drought stress depending on the way that the plant experiences water deficit. This differential response involves several mechanisms among which are osmotic regulation, the use of secondary metabolism, and redox regulation. Moreover, under our 
experimental conditions, the results also suggest that the mechanism used by chili pepper cultivar when facing strong water stress is oxidative regulation through activation of $S O D$ gene expression, and thus the enzyme superoxide dismutase (SOD) plays a major role.

Author Contributions: Conceptualization, I.M.-B. and I.T.-P.; formal analysis, R.G.G.-G. and I.T.-P.; funding acquisition, R.G.G.-G.; investigation, I.M.-B. and M.V.-H.; methodology, I.M.-B. and M.V.-H.; project administration, I.T.-P.; resources, E.R.-G. and R.V.O.-V.; supervision, R.V.O.-V. and I.T.-P.; validation, R.G.G.-G.; visualization, E.R.-G.; writing-review and editing, I.T.-P. and I.M.-B. All authors have read and agreed to the published version of the manuscript.

Funding: I.T.-P. and R.G.G.-G. thank to Ciencia Básica 2018 (SEPCONACYT A1-S-33677) and Ciencia Básica 2016 (SEPCONACYT 283259), respectively.

Acknowledgments: Israel Macias-Bobadilla acknowledges CONACYT of the grant support.

Conflicts of Interest: The authors declare no conflict of interest.

\section{References}

1. Heiser, C.B.; Pickersgill, B. Names for the cultivated capsicum species (Solanaceae). Int. Assoc. Plant Taxon. 1969, 18, 277-283. [CrossRef]

2. Orobiyi, A.; Dansi, M.; Assogba, P.; Loko, L.Y.; Vodouhe, R.S.; Akouegninou, A.; Sanni, A. Chili (Capsicum annuum L.) in southern Benin: Production constraints, varietal diversity, preference criteria and participatory evaluation. Int. Res. J. Agric. Sci. Soil Sci. 2013, 3, $2244-2251$.

3. González-Zamora, A.; Sierra-Campos, E.; Luna-Ortega, J.; Pérez-Morales, R.; Ortiz, J.; García-Hernández, J. Characterization of different capsicum varieties by evaluation of their capsaicinoids content by high performance liquid chromatography, determination of pungency and effect of high temperature. Molecules 2013, 18, 13471-13486. [CrossRef] [PubMed]

4. Vargas-Hernandez, M.; Macias-Bobadilla, I.; Guevara-Gonzalez, R.G.; Romero-Gomez, S.D.J.; Rico-Garcia, E.; Ocampo-Velazquez, R.V.; Alvarez-Arquieta, L.D.L.; Torres-Pacheco, I. Plant hormesis management with biostimulants of biotic origin in agriculture. Front. Plant Sci. 2017, 8, 1-11. [CrossRef] [PubMed]

5. Jaleel, C.; Manivannan, P.; Wahid, A.; Farooq, M.; Al-Juburi, H.; Somasundaram, R.; Panneerselvam, R. Drought Stress in Plants: A Review on Morphological Characteristics and Pigments Composition. Int. J. Agric. Biol. 2009, 11, 100-105.

6. Fahad, S.; Bajwa, A.A.; Nazir, U.; Anjum, S.A.; Farooq, A.; Zohaib, A.; Sadia, S.; Nasim, W.; Adkins, S.; Saud, S.; et al. Crop Production under Drought and Heat Stress: Plant Responses and Management Options. Front. Plant Sci. 2017, 8, 1147. [CrossRef]

7. Salehi-Lisar, S.Y.; Bakhshayeshan-Agdam, H. Drought Stress in Plants: Causes, Consequences, and Tolerance. In Drought Stress Tolerance in Plants, Vol 1; Hossain, M.A., Wani, S.H., Bhattacharjee, S., Burritt, D.J., Tran, L.-S.P., Eds.; Springer International Publishing: Cham, Switzerland, 2016; pp. 1-16, ISBN 978-3-319-28899-4.

8. Anjum, S.A.; Ashraf, U.; Tanveer, M.; Khan, I.; Hussain, S.; Shahzad, B.; Zohaib, A.; Abbas, F.; Saleem, M.F.; Ali, I.; et al. Drought Induced Changes in Growth, Osmolyte Accumulation and Antioxidant Metabolism of Three Maize Hybrids. Front. Plant Sci. 2017, 8, 69. [CrossRef]

9. Zhang, C.; Wang, X.; Zhang, F.; Dong, L.; Wu, J.; Cheng, Q.; Qi, D.; Yan, X.; Jiang, L.; Fan, S.; et al. Phenylalanine ammonia-lyase2.1 contributes to the soybean response towards Phytophthora sojae infection. Sci. Rep. 2017, 7, 7242. [CrossRef]

10. Wang, Z.; Yu, Q.; Shen, W.; El Mohtar, C.A.; Zhao, X.; Gmitter, F.G. Functional study of CHS gene family members in citrus revealed a novel CHS gene affecting the production of flavonoids. BMC Plant Biol. 2018, 18, 189. [CrossRef]

11. Lenk, I.; Fisher, L.; Vickers, M.; Akinyemi, A.; Didion, T.; Swain, M.; Jensen, C.; Mur, L.; Bosch, M. Transcriptional and Metabolomic Analyses Indicate that Cell Wall Properties are Associated with Drought Tolerance in Brachypodium distachyon. Int. J Mol. Med. 2019, 20, 1758. [CrossRef]

12. Zandalinas, S.I.; Mittler, R.; Balfagón, D.; Arbona, V.; Gómez-Cadenas, A. Plant adaptations to the combination of drought and high temperatures. Physiol. Plant. 2018, 162, 2-12. [CrossRef] [PubMed]

13. Hu, B.; Yao, H.; Peng, X.; Wang, R.; Li, F.; Wang, Z.; Zhao, M.; Jin, L. Overexpression of Chalcone Synthase Improves Flavonoid Accumulation and Drought Tolerance in Tobacco. Plant Sci. 2019. [CrossRef] 
14. Rodríguez-Calzada, T.; Qian, M.; Strid, Å.; Neugart, S.; Schreiner, M.; Torres-Pacheco, I.; Guevara-González, R.G. Effect of UV-B radiation on morphology, phenolic compound production, gene expression, and subsequent drought stress responses in chili pepper (Capsicum annuum L.). Plant Physiol. Biochem. 2019, 134, 94-102. [CrossRef] [PubMed]

15. Ighodaro, O.M.; Akinloye, O.A. First line defence antioxidants-superoxide dismutase (SOD), catalase (CAT) and glutathione peroxidase (GPX): Their fundamental role in the entire antioxidant defence grid. Alexandria J. Med. 2018, 54, 287-293. [CrossRef]

16. Gökmen, E.; Ceyhan, E. Effects of drought stress on growth parameters, enzyme activities and proline content in chickpea genotypes. Bangladesh J. Bot. 2018, 44, 177-183. [CrossRef]

17. Silva, A.; Ponce de León, J.; García, F.; Durán, A. Aspectos Metodologicos en la Determinacion de la Capacidad de Retener Agua de los Suelos del Uruguay; Universidad de la Republica/Facultad de Agronomia: Montevideo, Uruguay, 1988; p. 20.

18. Bates, L.S.; Waldren, R.P.; Teare, I.D. Rapid determination of free proline for water-stress studies. Plant Soil 1973, 39, 205-207. [CrossRef]

19. Livak, K.J.; Schmittgen, T.D. Analysis of Relative Gene Expression Data Using Real-Time Quantitative PCR and the $2^{-\Delta \Delta C T}$ Method. Methods 2001, 25, 402-408. [CrossRef]

20. De Beenhouwer, M.; Van Geel, M.; Ceulemans, T.; Muleta, D.; Lievens, B.; Honnay, O. Changing soil characteristics alter the arbuscular mycorrhizal fungi communities of Arabica coffee (Coffea arabica) in Ethiopia across a management intensity gradient. Soil Biol. Biochem. 2015, 91, 133-139. [CrossRef]

21. Ashraf, M.; Foolad, M.R. Roles of glycine betaine and proline in improving plant abiotic stress resistance. Environ. Exp. Bot. 2007, 59, 206-216. [CrossRef]

22. Fiasconaro, M.L.; Lovato, M.E.; Antolín, M.C.; Clementi, L.A.; Torres, N.; Gervasio, S.; Martín, C.A. Role of proline accumulation on fruit quality of pepper (Capsicum annuum L.) grown with a K-rich compost under drought conditions. Sci. Hortic. 2019, 249, 280-288. [CrossRef]

23. Kahlaoui, B.; Hachicha, M.; Misle, E.; Fidalgo, F.; Teixeira, J. Physiological and biochemical responses to the exogenous application of proline of tomato plants irrigated with saline water. J. Saudi Soc. Agric. Sci. 2018, 17, 17-23. [CrossRef]

24. Laxa, M.; Liebthal, M.; Telman, W.; Chibani, K. The role of the plant antioxidant system in drought tolerance. Antioxidants 2019, 8, 94. [CrossRef] [PubMed]

25. Das, K.; Roychoudhury, A. Reactive oxygen species (ROS) and response of antioxidants as ROS-scavengers during environmental stress in plants. Front. Environ. Sci. 2014, 2, 1-13. [CrossRef]

26. Wang, S.; Zhang, Q.; Zheng, S.; Chen, M.; Zhao, F.; Xu, S. Atrazine exposure triggers common carp neutrophil apoptosis via the CYP450s/ROS pathway. Fish Shellfish Immunol. 2019, 84, 551-557. [CrossRef]

27. Filomeni, G.; De Zio, D.; Cecconi, F. Oxidative stress and autophagy: The clash between damage and metabolic needs. Cell Death Differ. 2014, 22, 377. [CrossRef] [PubMed]

28. Zhai, Y.; Guo, M.; Wang, H.; Lu, J.; Liu, J.; Zhang, C.; Gong, Z.; Lu, M. Autophagy, a Conserved Mechanism for Protein Degradation, Responds to Heat, and Other Abiotic Stresses in Capsicum annuum L. Front. Plant Sci. 2016, 7, 131. [CrossRef] [PubMed]

29. Avin-Wittenberg, T. Autophagy and its role in plant abiotic stress management. Plant. Cell Environ. 2019, 42, 1045-1053. [CrossRef]

30. Liu, R.; Jiang, X.; Guan, H.; Li, X.; Du, Y.; Wang, P.; Mou, H. Promotive effects of alginate-derived oligosaccharides on the inducing drought resistance of tomato. J. Ocean Univ. China 2009, 8, 303-311. [CrossRef]

31. Ximénez-Embún, M.G.; González-Guzmán, M.; Arbona, V.; Gómez-Cadenas, A.; Ortego, F.; Castañera, P. Plant-mediated effects of water deficit on the performance of tetranychus evansi on tomato drought-adapted accessions. Front. Plant Sci. 2018, 9, 1490. [CrossRef]

(C) 2020 by the authors. Licensee MDPI, Basel, Switzerland. This article is an open access article distributed under the terms and conditions of the Creative Commons Attribution (CC BY) license (http://creativecommons.org/licenses/by/4.0/). 